\title{
COMMUNITY COMPETENCY IMPROVEMENT IN NORTH PETUKANGAN VILLAGE, SOUTH JAKARTA WITH MICROSOFT WORD TRAINING
}

\author{
Painem Painem ${ }^{1 *}$, Hari Soetanto ${ }^{1}$ \\ ${ }^{1}$ Faculty of Information Technology, Budi Luhur University \\ *painem@budiluhur.ac.id
}

\begin{abstract}
In the era of globalization like today, the need for information technology is very high. In daily activities, of course, cannot be separated from the use of computers. People need to add insight to the field of information technology, one of which is the use of Microsoft Word. Therefore, the implementation of this community service program intends to provide knowledge for the community around RT.002 / RW.011 Petukangan Utara Village, Pesanggrahan Sub-District, South Jakarta. This activity also aims to improve the quality of society in the field of Information Technology, especially Microsoft Word. The result of this activity is that the community is able to utilize Microsoft Word to help with various homework or office work. Also, this training is expected to be able to strengthen cooperation between Budi Luhur University and the community around RT.002 / RW.011, Petukangan Utara Village, Pesanggrahan District, South Jakarta. This activity is one manifestation of the Three Pillars of Higher Education comprising Education, Research and Community Service that must be carried out by each lecturer.
\end{abstract}

Keywords: Community, Microsoft Word, Training, education

\section{INTRODUCTION}

Technology and Information are currently developing in all Sectors. Therefore, increasing the competence of human resources in the field of technology and information is needed in the community, especially the community around RT.002 / RW.011 Petukangan Utara Village, Pesanggrahandistrict, South Jakarta. Increasing the competence of human resources is part of the goals in Indonesia's national development. One form of enhancing the competence of human resources in the field of technology and information is Microsoft Word training. Microsoft Word is one of the word processing software created by Microsoft and included in the Microsoft Office package(Lambert \& Frye, 2015). Microsoft Word training is one of the Three Pillars of Higher Education comprising Education, Research and Community Service which a lecturer must do is to do Community Service. Higher education is obliged to carry out research and community service besides carrying out education as mandated by Law Number 20 of 2003 concerning the National Education System Article 20. In line with these obligations, Law No. 12 of 2012 concerning Higher Education Article 45 confirms that research universities are directed to develop science and technology, as well as improve people's welfare and nation's competitiveness. In the article also affirmed that community service is an activity of academicians in practicing and cultivating science and technology to promote public welfare and educate the life of the nation.

Improving the quality of Human Resources with Microsoft Word training has been carried out in other agencies. As an example of Microsoft Word 2013 Application Training at Middle School "H.A. Johansyah. A. Banjarmasin"(Ikhwani, Budiman, \& Rasyidan, 2015), Microsoft Office Training in Biningkanaya Sub-district (Nas et al., 2017), Basic typing and word training for youth in Tanah Baru sub-district, BejiSubdistrict, Depok City (Tjahjono, 2014), Software Utilization Training (Microsoft Office Word, Excel, Power Point) in data processing performance in Village Government for Village Heads in BatangAngkola District (Sormin, Sahara, \& Agustina, 2018). We hope that this community 
service can be a useful contribution to improving the capacity of the community, sharpening systematic thinking or mindset. In addition, it is easy to receive more advanced information and not stutter in the technology zone.

\section{METHOD}

The method of training activities is carried out based on the process of theoretical and practical learning. Comparison between theoretical and practical learning ranges from a ratio of about 1: 2 . Training methods to convey theory, include lecture, question and answer and discussion, while the practicum consists of a question and answer method and a task or exercise.

\section{Observation}

This activity was carried out by visiting the service partners in some areas ofPetukangan Utara Village, Pesanggrahan Sub-District, South Jakarta to find out the needs of partners in the Community Service process. After knowing the needs of the partners, we formed a team as a result of the partner location survey.

\section{Interview}

Direct interviews were conducted with the Chairperson of the Neighborhood Association and residents about needs that could be used as objects of community service.

\section{Study Literature}

Study literature related to training themes, documentation of the partners and search for information from the internet about the latest conditions of the partner locations. Of the three methods of data collection above, we assemble the linkages between the activities we do between teams and users, as follows:

1. The team analyzes the needs of users to the RT.002 / RW.011 Region in Petukangan Utara Village, Pesanggrahan District, South Jakarta.

2. The Lecturer Team makes the results of the needs analysis by designing training needs.

3. Lecturers create training modules that will be used as a guide for trainees.

4. Students as assistant to Lecturers prepare for the implementation of the training.

5. Lecturers carry out training with students and evaluate trainees by giving training

The following is the material given during this Microsoft Word training:

1. Create and Store Word Documents

2. Run Microsoft Word 2016

3. Introduction to the Word 2016 Interface / Display

4. Create a New Document in Microsoft Word 2016

5. Storing Word Documents

6. Closing Word Documents

7. Editing Working Documents and Formatting Letters

8. Open a Word Document that has been saved

9. Selecting Text That Will Be Format / Edit

10. Formatting letters / fonts

11. Adjust the alignment and direction of the text

12. Setting Bullet and Numbering

13. Adjust Line Lines / Line Spacing

14. Set Margin, Size and Page Orientation / Page Size

15. Work with Headers \& Footers and Insert Symbols and Page Numbers

16. Making Headers and Footers

17. Removing Headers and Footers

18. Manipulate Tables

19. Set Border and Shading Tables

20. Inserting rows and columns in tables

21. Deleting Rows and Table Columns 
22. Adjust the Row Height and Column Width

23. Combining and separating rows and table columns

24. Insert Picture

25. Mail merge

\section{RESULT AND DISCUSSION}

Training in order to improve the quality of Human Resources through Microsoft Word computer training has generally been going well and smoothly. Participants who attended were RT.002 / RW.011 community in Petukangan Utara Village, Pesanggrahan District, South Jakarta. Participants also attended the training enthusiastically and passionately. However, there are several obstacles that need to be improved in the future. Materially, the results that can be obtained from this training activity are the participants are able to implement some of the features that exist in Microsoft Word properly, able to create tables to make lesson schedules accompanied by animations that have been provided in Microsoft Word, able to make invitation letters by utilizing the mail merge to include the names that are enacted. Figure 1 is one example of Microsoft Word training output.

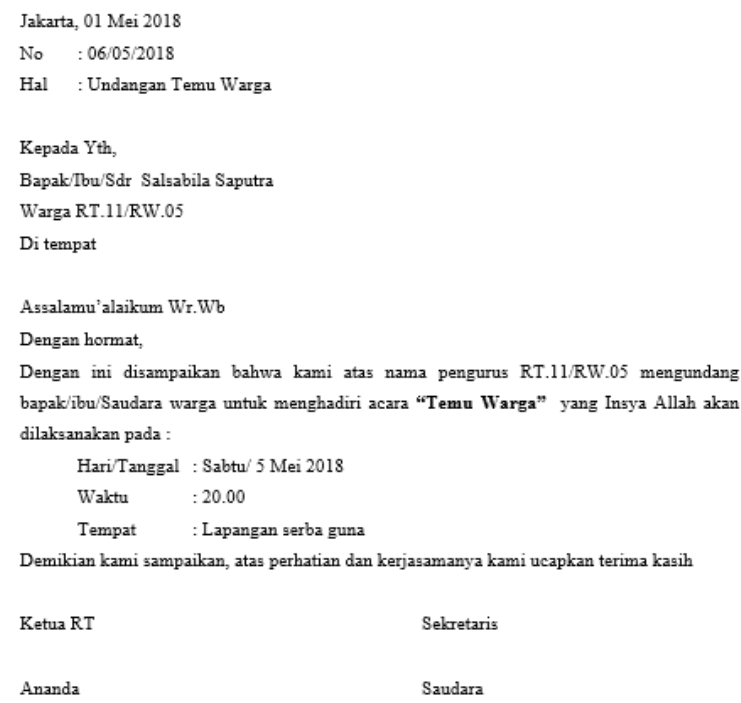

Figure 1. Example of Letter

Based on the results of the evaluation of the training held, it was concluded that participants could benefit from the implementation of Microsoft Word training. Figure 2 shows the results of the evaluation of the implementation of training obtained using the questionnaire method. 


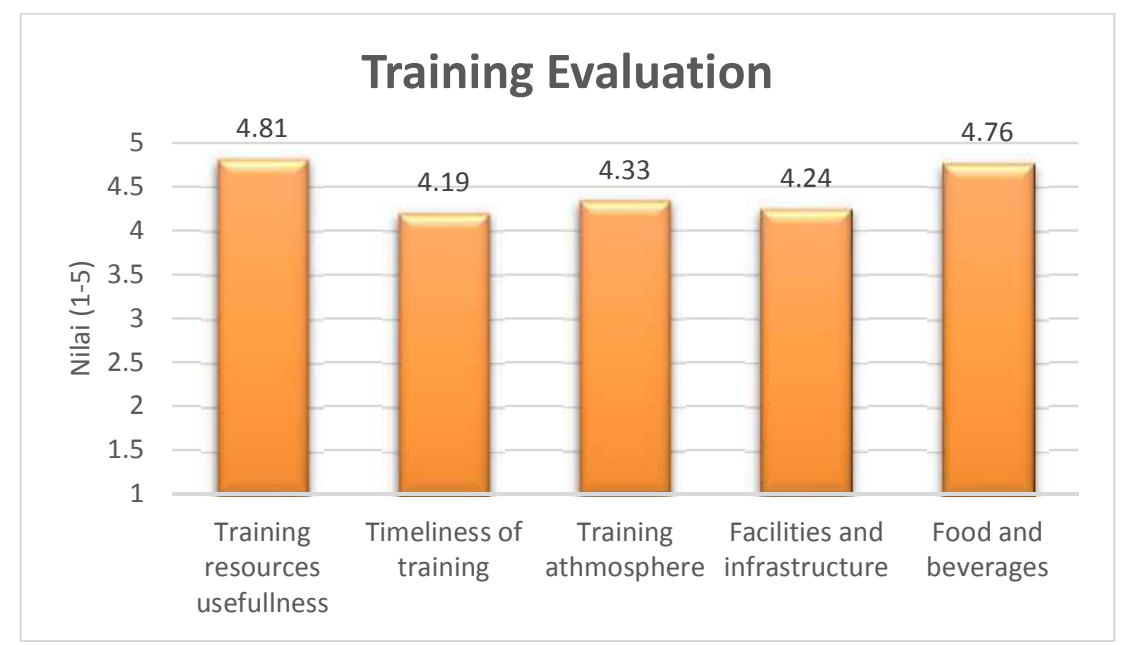

Figure 2. Training Evaluation

The things that still need to be improved from the implementation of the training are the timeliness of training, the availability of training facilities and infrastructure such as computers, stationery and so on, as well as a comfortable training atmosphere. In general, the training participants' assessment of the training was in a good category with a value of 4.47 in the range of 1-5. Meanwhile, judging from the participant's assessment of the instructor or resource person, it was seen that the participants were quite satisfied with the qualifications and material presented by the resource person. This can be seen in the results of the training participants' evaluation of the speakers presented in Figure 3. In general, all participants considered that the customer had mastered the material very well. It can be seen from the results of the evaluation in terms of material mastery, the average value was 4.81 in the 1-5 range. Based on the results of the participant's assessment, things need to be improved from the resource person, especially on how the resource person interacted with the trainees and the use of tools (Powerpoint, etc.). The resource person must be more interactive in providing material by giving more opportunities for participants to ask questions and understand the material in more depth.

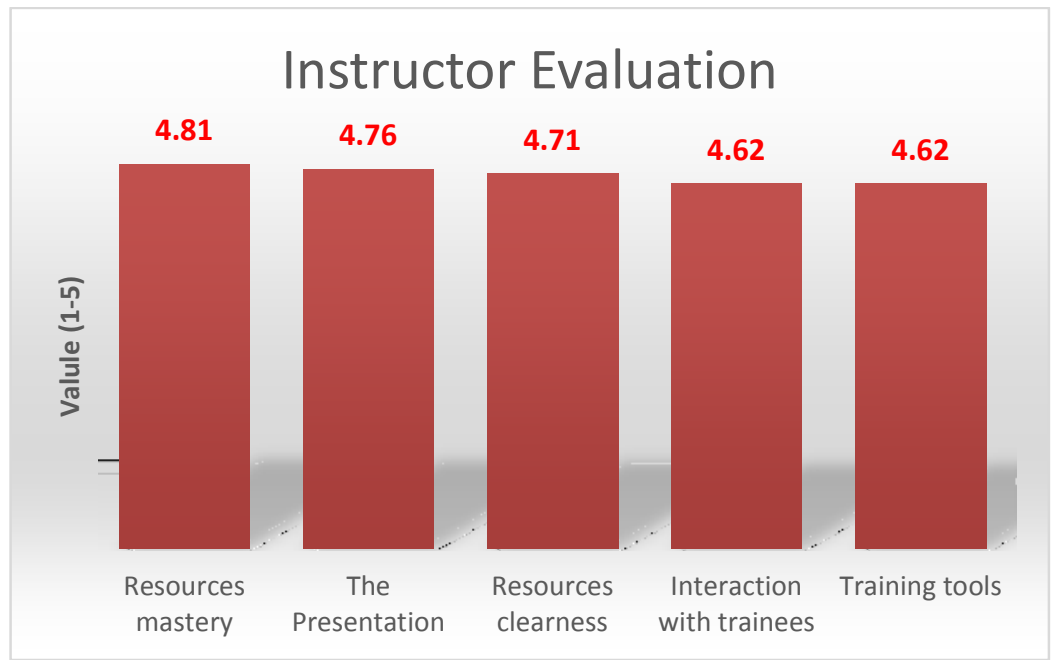

Figure 3. Instructor Training

Based on the results of the implementation of training, some things still need to be improved and improved in the future. Some notes on improving the quality of training in the future based on input from training participants including: 
- Availability of training facilities and infrastructure must be considered, especially computers that are installed with up-to-date Microsoft Word software

- If more training is held so that practice is increased rather than theory.

- Future training will still be carried out with the more in-depth material.

- More improved and remain passionate about providing the knowledge they have to make it more useful for many people.

- More often the training.

- Increase again in terms of material delivery.

- More activities need to be improved further training other Microsoft Office packages such as Excel, Powerpoint, and others

In addition, the implementation time also needs to be considered in conducting training. The timing of the less effective results in the presentation of less optimal training material. Some training materials cannot be delivered because of limited time to run. Training facilities and infrastructure can also be obstacles and need to be anticipated.

\section{CONCLUSION}

Based on the implementation and evaluation of training implementation, in general, there are several things that can be concluded, namely:

1. The implementation of the training went smoothly and was attended by residents around RT.02 / RW.11

2. The training material presented is how to utilize the features in Microsoft Word.

3. The evaluation results indicate that the trainees feel the benefits of the material provided. The average value of training is 4.47 and the assessment of instructors is 4.70 in the 1-5 range.

Meanwhile, the quality of training needs to be improved in the future. Some suggestions for the implementation of community service activities in the future:

1. Need training other than Microsoft Word such as Microsoft Excel, Powerpoint and others

2. Material tailored to the needs and competencies desired by the Citizens

3. The selection of training days should be considered properly so that material delivery is more effective and efficient.

4. Participants in the training were more expanded than RT.02 / RW.11 in Petukangan Utara village.

\section{REFERENCES}

ikhwani, Y., Budiman, H., \& Rasyidan, M. (2015). Pelatihan Aplikasi Microsoft Word 2013 Pada Smp Ha Johansyah. A Banjarmasin. Jurnal Pengabdian Al-Ikhlas Universitas Islam Kalimantan Muhammad Arsyad Al Banjary, 1(1).

Lambert, J., \& Frye, C. (2015). Microsoft Office 2016 (Vol. 2016). Washington: Microsoft Press.

Nas, M., Parenreng, M. M., Thaha, S., Jurusan, D., Elektro, T., Negeri, P., \& Pandang, U. (2017). Ibm Peningkatan Mutu Sdm Untuk Perbaikan Pelayanan Kepada Masyarakat Pada Kecamatan Biringkanaya. In Prosiding Seminar Hasil Pengabdian Kepada Masyarakat (Pp. 459-461).

Sormin, M. A., Sahara, N., \& Agustina, L. (2018). Pelatihan Pemanfaatan Perangkat Lunak (Microsoft Office Word, Excel, Power Point) Dalam Kinerja Pengolahan Data Di Pemerintahan Desa Bagi Kepala Desa Se-Kecamatan Batang Angkola. Martabe: Jurnal Pengabdian Masyarakat, 1(2), $78-82$.

Tjahjono, B. (2014). Pelatihan Dasar Pengetikan Dan Ms-Word Untuk Karang Taruna Kelurahan Tanah Baru Kecamatan Beji Kota Depok. Jurnal Abdimas, 1(1). 
